Boston University School of Law Scholarly Commons at Boston University School of Law

Faculty Scholarship

2009

\title{
How Medicare Could Get Better Prices on Prescription Drugs
}

Kevin Outterson

Boston Univeristy School of Law

Follow this and additional works at: https://scholarship.law.bu.edu/faculty_scholarship

Part of the Health Law and Policy Commons

\section{Recommended Citation}

Kevin Outterson, How Medicare Could Get Better Prices on Prescription Drugs, 28 Health Affairs 832 (2009).

Available at: https://scholarship.law.bu.edu/faculty_scholarship/493

This Article is brought to you for free and open access by Scholarly Commons at Boston University School of Law. It has been accepted for inclusion in Faculty Scholarship by an authorized administrator of Scholarly Commons at Boston University School of Law. For more information, please contact lawlessa@bu.edu. 


\section{How Medicare Could Get Better Prices On Prescription Drugs}

Increased formulary flexibility and value-based pricing are among the options that should be considered in the context of health reform.

\section{by Kevin Outterson and Aaron S. Kesselheim}

ABSTRACT: Congress may reform drug pricing policies under Medicare Part $D$ as part of a larger health reform effort. Currently, the "noninterference" provision prevents the government from negotiating drug prices on behalf of Medicare Part D prescription drug plans. Commonly considered reform proposals borrow ideas from Medicaid, either through returning dual eligibles to Medicaid drug pricing or by imposing mandatory rebates across the Part D population. We examine a menu of other options, including value-based pricing; expansion of generic and therapeutically equivalent substitution; increased formulary diversity; importation; and limited antitrust waivers. These latter options may reduce federal spending without direct government price negotiations. [Health Aff (Millwood) 2009;28(5): w832-41 (published online 30 July 2009;10.1377/hlthaff.28.5.w832)]

N \$8O B I L LIO N INFORMAL A GREEMENT by the drug industry to support
Medicare and Medicaid drug benefits has raised the profile of the costly
Medicare Part D prescription drug program as Congress crafts broad health care reform legislation. The 1llth Congress may address several aspects of Part D for legislative reform, including the "noninterference" provision in the Medicare Prescription Drug, Improvement, and Modernization Act (MMA) of 2006, which says that the secretary of Health and Human Services (HHS) cannot "interfere with the negotiations" or "institute a price structure" for Part D drugs. Prohibiting such negotiations has been criticized as artificially raising Part D drug prices and increasing the costs of the program. ${ }^{l}$ With the noninterference provision in place, price negotiations occur at the level of the individual Part D insurance plans, using private-sector purchasing strategies.

In this paper we evaluate several options to reduce federal spending on Part D drugs (Exhibit 1), focusing on the most feasible ideas. We first examine federal ne-

Kevin Outterson (mko@bu.edu) is an associate professor in the Boston University School of Law in Massachusetts. Aaron Kesselheim is an instructor in medicine, Division of Pharmacoepidemiology and Pharmacoeconomics, Department of Medicine, at Brigham and Women's Hospital and Harvard Medical School in Boston. 


\section{EXHIBIT 1}

Medicare Part D Drug Price Reform Options

\begin{tabular}{|c|c|c|}
\hline Category/proposal $^{\mathrm{a}}$ & Strengths & Weaknesses \\
\hline \multicolumn{3}{|l|}{ Direct federal interventions } \\
\hline Price controls & Large static savings & $\begin{array}{l}\text { Administratively complex; political process } \\
\text { vulnerable to lobbying; formidable political } \\
\text { opposition }\end{array}$ \\
\hline International reference pricing & $\begin{array}{l}\text { Large static savings; administratively } \\
\text { straightforward }\end{array}$ & $\begin{array}{l}\text { Savings tend to dissipate over time as } \\
\text { companies react; policy levers ceded to } \\
\text { referenced reimbursement systems }\end{array}$ \\
\hline Profit controls & Existing model in U.K. & $\begin{array}{l}\text { Largely ineffective due to company } \\
\text { reactions to profit-based measures } \\
\text { (transfer pricing) }\end{array}$ \\
\hline Federal negotiations & $\begin{array}{l}\text { Direct federal role without a } \\
\text { complicated administrative process }\end{array}$ & $\begin{array}{l}\text { Horizontal inequity; unknown effectiveness; } \\
\text { rent seeking }\end{array}$ \\
\hline Binding arbitration & Evidence-based legal process & $\begin{array}{l}\text { Companies have opposed similar } \\
\text { processes in NICE and PBS }\end{array}$ \\
\hline Public option plans & $\begin{array}{l}\text { Limited scope, leaving the remainder } \\
\text { of the market untouched }\end{array}$ & Political opposition; unknown effectiveness \\
\hline \multicolumn{3}{|l|}{ Medicaid-based } \\
\hline Mandatory rebates & $\begin{array}{l}\text { Huge static savings with well-tested } \\
\text { administrative model }\end{array}$ & $\begin{array}{l}\text { Arbitrary rebate levels; company responses } \\
\text { will erode savings over time }\end{array}$ \\
\hline $\begin{array}{l}\text { Return dual eligibles to Medicaid } \\
\text { pricing }\end{array}$ & $\begin{array}{l}\text { Significant static savings; known } \\
\text { implementation model }\end{array}$ & One-time clinical cost of switching back \\
\hline \multicolumn{3}{|l|}{ Other proposals } \\
\hline Formulary design & $\begin{array}{l}\text { Permits Part D plans to use } \\
\text { commercial formulary designs; } \\
\text { significant savings }\end{array}$ & $\begin{array}{l}\text { Savings will take time; formulary } \\
\text { restrictions have clinical effects; patients } \\
\text { must make educated choices; opposition } \\
\text { by patient advocacy groups }\end{array}$ \\
\hline Generic and therapeutic substitution & Extends a proven savings model & $\begin{array}{l}\text { Expansion to therapeutic classes and } \\
\text { biosimilars may have clinical effects }\end{array}$ \\
\hline Antitrust waivers & Low risk & Unproven \\
\hline Importation & Some static savings & $\begin{array}{l}\text { Secondary effects in foreign markets; } \\
\text { potential safety questions; savings unlikely } \\
\text { to persist; cedes policy levers to foreign } \\
\text { reimbursement systems }\end{array}$ \\
\hline Value-based pricing & $\begin{array}{l}\text { Transformative information spillovers } \\
\text { to U.S. health care market; significant } \\
\text { existing international evidence base } \\
\text { and U.S. commitment to fund } \\
\text { additional studies }\end{array}$ & $\begin{array}{l}\text { Some have tried to create tension between } \\
\text { comparative effectiveness and cost- } \\
\text { effectiveness; history of political opposition } \\
\text { to NICE and PBS determinations; lag time } \\
\text { for new studies }\end{array}$ \\
\hline
\end{tabular}

SOURCE: Authors' analysis.

NOTES: NICE is (U.K.) National Institute for Health and Clinical Effectiveness. PBS is (Australian) Pharmacy Benefits Scheme.

${ }^{a}$ All proposals share the potential for dynamic changes to research and development.

gotiations and other direct interventions in the Part D market; we then turn to approaches that avoid direct government price negotiations.

\section{Direct Federal Negotiations}

In the years since Part D was enacted, a number of reform proposals have sought 
to overturn the noninterference provision. The most straightforward plan would simply remove the offending section from MMA. But the structure of Part D, replete with many private plans, poses difficult administrative and practical hurdles to successful federal price negotiation. ${ }^{2}$ The Congressional Budget Office (CBO) concluded that HHS would have insufficient leverage to negotiate on behalf of plans, given that discounts are driven more by moving market share in competitive drug classes than by gross volume. ${ }^{3}$

In addition, the largest Part D contractors compete across many health insurance markets, and it is unclear how federally negotiated prices under Part D could be limited to Medicare. Negotiators would need to account for favorable price discrimination in other U.S. programs and protect low-cost federal acquisition programs such as the Section 340b public health program and the Federal Supply Schedule (FSS). ${ }^{4}$ A recent analysis projected $\$ 21.9$ billion in annual savings if Part D adopted FSS pricing. ${ }^{5}$ However, if Part D and FSS prices are linked, the FSS may no longer be able to achieve the same discounts. This dynamic effect might greatly reduce the net savings to the federal government.

- Negotiations for a public drug plan. Another direct federal approach proposed in recent legislative sessions ${ }^{6}$ would require negotiations, but only for a publicly owned drug plan. ${ }^{7}$ Leading congressional Democrats support a "public plan option" for health reform generally; the public plan would negotiate prices, but only for itself. Successful negotiations would require a credible threat of formulary exclusion, which is difficult in a national public plan with a safety-net role.

Other direct interventions. Other direct federal interventions have also been discussed-including international reference pricing, price controls, profit limitations, ${ }^{8}$ and binding arbitration for sole-source Part D drugs. ${ }^{9}$ All of these proposals face strong political opposition in the United States, with the possible exception of the arbitration proposal.

\section{Medicaid-Based Pricing: Dual Eligibles And Rebates}

A second category of reforms borrows ideas from the Medicaid program. Medicaid receives substantial discounts on drugs, in both mandatory federal rebates and state-negotiated supplemental rebates. A House committee has estimated that Part D pays about 30 percent higher drug prices than Medicaid pays. ${ }^{10}$ Congress moved Medicaid patients who were also eligible for Part D (so-called dual eligibles) into Medicare Part D, meaning that such patients lost access to Medicaid rebates. Although patients' experiences have been mixed, studies have revealed that certain high-risk patients had problems maintaining access after the switch. ${ }^{11,12}$ State budgets did not benefit, as state Medicaid savings were recovered by a federal charge called the "clawback," which led to unsuccessful litigation by some states against the federal government before the Supreme Court. ${ }^{13}$

- Mandatory rebates. Two Medicaid-based pricing proposals have recently been discussed. The greatest direct cost savings would come from applying the 
Medicaid mandatory rebate scheme to Part D. The CBO estimated that a 15 percent mandatory rebate would reduce federal expenses by $\$ 33$ billion in 2010-2014 and $\$ 110$ billion in 2010-2019. ${ }^{2}$ Mandatory rebates are economically similar to a federal tax on the patent-based drug industry, with the proceeds supporting Part D. This model has the benefit of simplicity, and it may be reasonable to require participating companies to directly support a system that has been so profitable for them. However, mandatory rebates would be prone to gaming by companies and politically expedient adjustments by Congress, which could revisit the relatively arbitrary rebate level in the future. All of the options would also reduce drug company profits. ${ }^{14}$

Return dual eligibles to Medicaid pricing. The second, perhaps more feasible, step would return the 6.2 million dual eligibles to Medicaid pricing, which could lead to substantial savings ${ }^{15}$ - perhaps as much as $\$ 2.8$ billion annually. ${ }^{16}$ As Richard Frank and Joseph Newhouse have suggested, this step involves less risk, since major problems were not apparent under the prior regime. ${ }^{9}$

\section{Reforms To Promote More-Effective Private Negotiations}

Other possible reforms seek to improve private negotiations by Part D plans. We evaluate a menu of five options that could effectively give more negotiating power to Part D plans. These proposals retain the current framework of a competitive prescription drug marketplace, with less-intrusive government intervention.

- Formulary design flexibility. Formulary design is a widely used privatesector tool for controlling health plans' drug costs. Medicare limited the freedom of Part D plans to control their formularies through rules such as the safe harbor guidelines established by the U.S. Pharmacopeia ${ }^{17}$ and MMA's requirement that Part D plans cover at least two drugs per class. ${ }^{18}$

The CMS went beyond the statute, requiring at least one drug in each subclass as well. In addition, the CMS has given special protections to six classes of drugs, requiring that "all or substantially all drugs" in the classes be included in the formularies. ${ }^{18}$ This rule effectively eliminates Part D drug price negotiations over anticonvulsants, antidepressants, antineoplastics, antipsychotics, antiretrovirals, and immunosuppressants. In other classes, Part D plans routinely exclude some drugs as part of the normal commercial formulary process. ${ }^{19}$ The 110th Congress solidified and expanded the protected classes. The July 2008 physician payment update legislation gave the CMS clear statutory authority to expand the protected drug classes and created a cumbersome process that delays competition within the classes. ${ }^{20}$

These rules limit the negotiating power of Part D plans and make drugs in those classes more expensive. A Milliman study found that these six protected classes accounted for 16.8-33.2 percent of Part D drug costs by Part D plan administrators. Reversing this one rule would decrease prices in these classes by 9-1l percent, for a projected Part D savings of $\$ 511$ million per year. ${ }^{21}$ To ease the negative effect such restrictions can have on price negotiations, Congress could modify the 
Medicare Part D rules to give private drug plans more freedom to control their formularies. More-flexible formularies would permit more-aggressive negotiations by Part D plans, because the plans would have more maneuvering room to negotiate for deeper discounts, as they do with some of their non-Medicare plans. ${ }^{22}$

Because permitting tighter formularies for Part D plans could have real clinical and financial effects, modifications would have to be monitored closely. For example, tighter formularies might be adopted by Medicare Advantage Prescription Drug (MA-PD) plans as a device to discourage enrollment by beneficiaries with certain chronic conditions. In the absence of effective risk adjustments in Medicare contracts, experimentation with tighter formulary designs might be limited to stand-alone plans. In addition, formulary stability is important; rules should continue to prohibit changes that negatively affect a Part D formulary or drug tier structure within a plan year. ${ }^{23}$ Patients will need to be aware of the changes in their plan well in advance of the annual enrollment period, but Medicare patients do not have a good track record in efficiently selecting Part D plans. ${ }^{24}$ Plans could be required to give beneficiaries advance notice of any prospective formulary or tier design change affecting any drug purchased in the prior three years.

Current Medicare rules allow some midyear benefit alterations that could directly affect patient care, in the form of drug price changes at the point of purchase. These changes can occur without notice, even after a beneficiary has committed to a particular plan. Physicians and policymakers should be concerned about the potential risks this current arrangement may pose for patients. This proposal is not a national formulary; it simply permits more heterogeneity among private formularies.

Extended generic and therapeutic substitution. Substitution of generic drugs for their brand-name equivalents is well established as a way of reducing what consumers and health plans pay for prescription drugs without affecting clinical outcomes. ${ }^{25}$ It is important to note that generic substitution strategies to date have been effective, and their history of success may limit future potential savings. ${ }^{26}$

State generic substitution laws vary widely in their effectiveness, and consumers' willingness to switch voluntarily is less than optimal. ${ }^{27}$ In some states, laws have been proposed to reduce the scope of generic substitution for certain classes of drugs. A federal generic substitution law is a possible response: it would preempt local legislative retrenchments and promote uniform generic access.

Some will argue that these changes are not needed, since Medicare Part D plans already have substantial and growing generic use rates (Exhibit 2), but expanded generic substitution would accelerate this trend. Medicare Part D plans vary greatly in generic use rates, ranging in 2008 from a high of 89.5 percent to a low of 49.1 percent. ${ }^{28}$ These variations may represent consumers' preferences among the various plan designs, as patients who are unwilling or unable to accept particular generics choose higher-price plans. But given the clinical equivalence of nearly all brand-name and generic drugs, ${ }^{29}$ there may still be room for improving generic 


\section{EXHIBIT 2}

Quarterly Use Of Generic Drugs In Medicare Part D, As Percentage Of Paid Part D Claims, 2006-2008

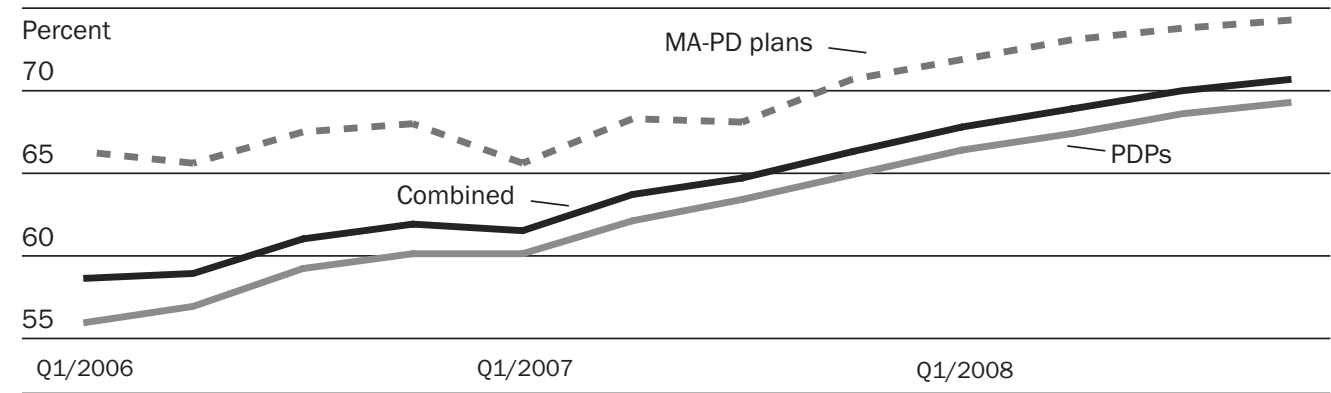

SOURCE: Centers for Medicare and Medicaid Services, Medicare Part D Generic Drug Utilization Rates (2006-2008), NOTES: MA-PD is Medicare Advantage prescription drug. PDP is prescription drug plan.

substitution rates.

Another way to achieve price savings would be to expand generic substitution laws to include different drugs within carefully selected therapeutic classes, including between similar biologic molecules. Congress is considering a form of therapeutic substitution legislation to permit "generic" biological molecules, known as "biosimilars" or "follow-on biologics." Current law for generic entry of small-molecule chemicals is inadequate for more complex large-molecule biological products. The CBO estimates savings at $\$ 9.2-\$ 12$ billion over ten years if the federal law is changed to permit follow-on biologics. ${ }^{2}$ However, it is important to remember the role of state generic substitution laws, as well, to aid in the uptake of follow-on biologics.

Therapeutic substitution can also occur with traditional, nonbiological drugs. The clinical implications of therapeutic substitution must be addressed, because not all drugs within a class are substitutable for all patients. In December 2008 the CBO described a proposed Medicaid therapeutic substitution program in two classes: proton-pump inhibitors and non-benzodiazepine hypnotic agents for treating insomnia. ${ }^{2}$ Although the initial savings are projected to be quite small, this important trial of therapeutic substitution could be implemented and carefully evaluated for future expansions.

Generic utilization can also be supported by reference-based copayment structures. This copayment is the difference between the generic and brand-name price when a generic is available. In January 2009 the CMS proposed a ban on referencebased copays ${ }^{30}$ and other variable copayments, to take effect in 2010. The rule was finalized in the 2010 Call Letter issued 30 March 2009. ${ }^{31}$ Consumer groups such as AARP complained about reference-based copays in Part D plans, even though they apply only when a generic is available but not chosen by the patient. In this circumstance, the additional financial burden is probably justified, especially if the patient is clearly informed of the lower-cost generic option at the pharmacy. 
- Limited antitrust waivers. Antitrust laws prohibit joint negotiations by Medicare drug plans — such plans must all negotiate individually or through pharmacy benefit managers (PBMs). Such arrangements limit the market power of Part D plans. To address this problem, Congress could give private plans limited waivers from state and federal antitrust laws, allowing them to voluntarily band together in negotiating groups to seek lower drug prices. The waiver groups could be limited to no more than one-quarter of the Part D market, allowing a reasonable size to negotiate better discounts, without creating a monopsony, where a single buyer would have disproportionate leverage.

Although this option is straightforward in theory, it is hard to know in advance whether companies would use it. The larger companies might prefer to continue to negotiate independently. But smaller plans lacking market power might find this option attractive, especially if the joint negotiations were facilitated through their PBMs. Frank and Newhouse suggest that the market for Medicare prescription drug plans (PDPs) might be too fragmented, leaving some plans with "weaker than anticipated" negotiating power. ${ }^{9}$ If so, limited antitrust waivers might be able to recalibrate the market.

- Importation. For several years, Congress has considered various proposals to import lower-price drugs from countries with well-regulated pharmaceutical markets, such as Canada, Australia, and western Europe. Such a system was most recently proposed in 2009, permitting imports by individual patients and drug wholesalers from an FDA-approved set of sources. ${ }^{32}$ Additional legislation might not even be necessary, as HHS could use existing statutory authority to certify the safety of imports. ${ }^{33}$ Alternatively, Part D plans could agree to waive the right to import certain drugs in exchange for price discounts from the manufacturer. This waiver option reduces prices without invoking potential problems with importation. ${ }^{34}$

However, importation plans raise important questions, such as sustainability and the long-term dynamic effects on global prices and research and development (R\&D).$^{35}$ Arbitrage or parallel trade involves moving identical products from lowprice to higher-price markets, earning a profit on the difference. Over time, companies react to parallel trade to limit its scope and profitability. Also, although questions are often raised about safety, a fully regulated importation process will be much safer than the unregulated Internet and personal channels that some patients use now.

Value-based pricing. As a direct result of the quality movement in health care, Medicare is exploring important changes in how to pay for health services, including comparative effectiveness and value-based pricing incentives. ${ }^{36}$

Comparative effectiveness studies may include head-to-head trials of competing drugs, expanding the scope of evidence-based medicine. The American Recovery and Reinvestment Act of 2009 (the so-called stimulus bill) provided \$1.1 billion to fund research comparing the effectiveness of health care treatments. It also established the Federal Coordinating Council for Comparative Effectiveness Re- 
search, which will conduct this research along with HHS, the National Institutes of Health (NIH), and the Agency for Healthcare Research and Quality (AHRQ).

Value-based pricing for drugs adds the element of pharmacoeconomic analysis to comparative effectiveness data. It may require greater reimbursement for outstanding drugs with clear benefits over existing therapies, and less for drugs with limited usefulness or complicated side-effect profiles. ${ }^{37}$ Although value-based pricing does not necessarily lower the price of prescription drugs, its goal is to identify and encourage the use of more cost-effective medicines. A limited domestic test of value-based reimbursement in Part D could be an important step forward, as recently proposed by the Medicare Payment Advisory Commission (MedPAC) ${ }^{38}$

These U.S. efforts do not proceed in a vacuum. For the past decade, the National Institute for Health and Clinical Excellence (NICE) in England has performed comparative pharmacoeconomic and clinical analyses of drugs. ${ }^{39,} 40$ Other programs include the Australian Pharmaceutical Benefits Scheme ${ }^{41}$ and Oregon's Drug Effectiveness Review Project. ${ }^{42}$ A sizable international evidence base already exists, and the United States should examine the lessons learned in England and Australia. ${ }^{43}$ These results could inform the organization of the Part D plans in their formularies, payment tiers, and step-therapy options, with spillover benefits well beyond Medicare. A value-based reimbursement system could create and apply information in transformative applications for public and private health care markets. $^{44}$

\section{Concluding Remarks}

If Congress reforms Part D, it may be tempted to pursue interventions such as direct repeal of the noninterference provision or mandatory rebates. Restoring dual-eligible pricing is the better Medicaid-based strategy, especially if it can be done without harming patients, the states, and providers. One option would be to adopt dual-eligible pricing without actually moving dual eligibles' prescription drug financing back to Medicaid. In addition, more market-based reforms include greater formulary flexibility, expanded generic and therapeutic substitution, antitrust waivers, drug importation, and value-based reimbursement. Each of these reforms also suffers from various weaknesses, but they may be worth considering as positive steps toward achieving lower prices for prescription drugs within Medicare Part D and encouraging enrollees and their physicians to use effective, yet less expensive, medicines.

The authors report no conflict-of-interest disclosures.

\section{NOTES}

1. Families USA. No bargain: Medicare drug plans deliver high prices [Internet]. Washington (DC): Families USA; 2007 Jan [cited 2009 Jun 1l]. Available from: http://www.familiesusa.org/assets/pdfs/no-bargainmedicare-drug.pdf 
2. Congressional Budget Office. Budget options volume I: health care [Internet]. Washington (DC): CBO; 2008 Dec [cited 2009 Jun 11]. Available from: http:/www.cbo.gov/ftpdocs/99xx/doc9925/12-18-Health Options.pdf

3. CBO. Issues regarding drug price negotiation in Medicare, letter to the Honorable Ron Wyden [Internet]. Washington (DC): CBO: 2007 Apr 10 [cited 2009 Jun ll]. Available from: http://www.cbo.gov/ftpdocs/ 79xx/doc7992/DrugPriceNegotiation.pdf

4. U.S. Government Accountability Office. Prescription drugs: expanding access to federal prices could cause other price changes [Internet]. Washington (DC): GAO; 2000 Aug [cited 2009 Jun 11]. Available from: http://www.gao.gov/archive/2000/he00118.pdf

5. Gellad WF, Schneeweiss S, Brawarsky P, Lipsitz S, Haas JS. What if the federal government negotiated pharmaceutical prices for seniors? An estimate of national savings. J Gen Intern Med. 2008;23(9):1435-40.

6. Medicare Prescription Drug Savings and Choice Act, S 330, lllth Cong., lst Sess. (2009).

7. Lopert R, Moon M. Toward a rational, value-based drug benefit for Medicare. Health Aff (Millwood). 2007;26(6):1666-73.

8. Dicken JE. An overview of approaches to negotiate drug prices used by other countries and US private payers and federal programs. Washington (DC): GAO; 2007 Jan 1l. Report no. GAO-070358T.

9. Frank RG, Newhouse JP. Should drug prices be negotiated under Part D of Medicare? And if so, how? Health Aff (Millwood). 2008;27(1):33-43.

10. House Committee on Oversight and Government Reform, Majority Staff. Medicare Part D: drug pricing and manufacturer windfalls [Internet]. Washington (DC): U.S. House of Representatives; 2008 Jul [cited 2009 Jun 11]. Available from: http://oversight.house.gov/documents/20080724101850.pdf

11. West JC, WilkJE, Muszynski IL, Rae DS, Rubio-Stipec M, Alter CL, et al. Medication access and continuity: the experiences of dual-eligible psychiatric patients during the first four months of the Medicare prescription drug benefit. Am J Psychiatry. 2007;164(5):789-96.

12. Shrank WH, Patrick AR, Pedan A, Polinski JM, Varasteh L, Levin R, et al. The effect of transitioning to Medicare Part D drug coverage in seniors dually eligible for Medicare and Medicaid. J Am Geriatr Soc. 2008;56(12):2304-10.

13. Texas v. Leavitt, 547 US 1204 (2006).

14. Outterson K. Pharmaceutical arbitrage: balancing access and innovation in international prescription drug markets. Yale J Health Policy Law Ethics. 2005;5(1):193-291.

15. Schoen C, Guterman S, Shih A, Lau J, Kasimow S, Gauthier A, et al. Bending the curve: options for achieving savings and improving value in U.S. health spending [Internet]. New York (NY): Commonwealth Fund; 2007 Dec 18 [cited 2009 Jun 11]. Available from: http://www.commonwealthfund.org/Content/ Publications/Fund-Reports/2007/Dec/Bending-the-Curve--Options-for-Achieving-Savings-andImproving-Value-in-U-S-Health-Spending.aspx

16. U.S. House Committee on Oversight and Government Reform, Majority Staff. Private Medicare drug plans: high expenses and low rebates increase the costs of Medicare drug coverage [Internet]. Washington (DC): U.S. House of Representatives; 2007 Oct [cited 2009 Jun 1l]. Available from: http://oversight.house .gov/documents/20071015093754.pdf

17. U.S. Pharmacopeia. Revising the Medicare model guidelines. Rockville (MD): U.S. Pharmacopeia; 2004 Dec 31 [cited 2009 Jul 15]. Available from: http://www.usp.org/hqi/mmg/revisions.html

18. Centers for Medicare and Medicaid Services. Medicare Modernization Act: 2007 final guidelines-formularies [Internet]. Baltimore (MD): CMS; 2007 [cited 2009 Jun 1l]. Available from: http://www.cms.hhs .gov/PrescriptionDrugCovContra/DOWNLOADS/CY07formularyguidance.pdf

19. Medicare Payment Advisory Commission. A data book: healthcare spending and the Medicare program [Internet]. Washington (DC): MedPAC; 2008 Jun [cited 2009 Jun 1l]. Available from: http://www.medpac gov/documents/Jun08DataBook_Entire_report.pdf

20. Medicare Improvements for Patients and Providers Act, PL 110-275 (2008 Jul 15).

21. Kipp RA, Ko C. Potential cost impacts resulting from CMS guidance on special protections for six protected drug classifications and Section 176 of the Medicare Improvements for Patients and Providers Act of 2008 (MIPPA) (P.L. 110-275) [Internet]. Academy of Managed Care Pharmacy; 2008 Oct 16 [cited 2009 Jun 1l]. Available from: http://www.amcp.org/amcp.ark?p=AA8CD7EC

22. CBO. Prescription drug pricing in the private sector [Internet]. Washington (DC): CBO; 2007 Jan [cited 
2009 Jun 11]. Available from: http://www.cbo.gov/ftpdocs/77xx/doc7715/01-03-PrescriptionDrug.pdf

23. Block AL. Letter to Part D sponsors: formulary changes during the plan year [Internet]. Baltimore (MD): CMS; 2006 Apr 27 [cited 2009 Jun 11]. Available from: http:/www.cms.hhs.gov/PrescriptionDrug CovContra/downloads/MemoFormularyChangeGuidance_04.27.06.pdf

24. Gruber J. Choosing a Medicare Part D plan: are Medicare beneficiaries choosing low-cost plans? [Internet]. Menlo Park (CA): Kaiser Family Foundation; 2009 Mar [cited 2009 Jun 11]. Available from: http://www.kff.org/medicare/upload/7864.pdf

25. Kesselheim AS, Fischer MA, Avorn J. Extensions of intellectual property rights and delayed adoption of generic drugs: effects on Medicaid spending. Health Aff (Millwood). 2006;25(6):1637-47.

26. Aitken M, Berndt ER, Cutler DM. Prescription drug spending trends in the United States: looking beyond the turning point. Health Aff (Millwood). 2009;28(1):wl51-60.

27. Shrank WH, Cox ER, Fischer MA, Mehta J, Choudhry NK. Patients' perceptions of generic medications. Health Aff (Millwood). 2009;28(2):546-56.

28. CMS. Part D generic drug utilization rates (2006-2008) [Internet]. Baltimore (MD): CMS; 2009 May 28 [cited 2009 Jun 1l]. Available from: http://www.cms.hhs.gov/PrescriptionDrugCovGenIn/06_Performance Data.asp

29. Nightingale SL. Therapeutic equivalence of generic drugs: letter to health practitioners [Internet]. Rockville (MD): Food and Drug Administration; 1998 Jan 28 [cited 2009 Jun 11]. Available from: http:// www.fda.gov/Drugs/DevelopmentApprovalProcess/HowDrugsareDevelopedandApproved/Approval Applications/AbbreviatedNewDrugApplicationANDAGenerics/ucm073182.htm

30. This practice is sometimes called reference-based pricing, but it is distinct from international reference pricing.

31. Blum J. Issuance of the 2010 Call Letter [Internet]. Baltimore (MD): CMS; 2009 Mar 30 [cited 2009 Jun 11] Available from: http:/www.cms.hhs.gov/PrescriptionDrugCovContra/Downloads/2010CallLetter.pdf

32. Pharmaceutical Market Access and Drug Safety Act, S 525, lllth Cong., lst Sess. (2009).

33. Anderson GF, Shea DG, Hussey PS, Keyhani S, Zephyrin L. Doughnut holes and price controls. Health Aff (Millwood). 2004;23:w4-396-404

34. Kesselheim AS, Choudhry NK. The international pharmaceutical market as a source of low-cost prescription drugs for U.S. patients. Ann Intern Med. 2008;148(8):614-9.

35. Danzon PM. Closing the doughnut hole: no easy answers. Health Aff (Millwood). 2004;23:w4-405-8.

36. MedPAC. Report to the Congress: reforming the delivery system [Internet]. Washington (DC): MedPAC; 2008 Jun [cited 2009 Jun 11]. Available from: http://www.medpac.gov/documents/Jun08_EntireReport.pdf

37. Jayadev A, Stiglitz J. Two ideas to increase innovation and reduce pharmaceutical costs and prices. Health Aff (Millwood). 2008;28(1):wl65-8.

38. MedPAC. Report to the Congress: improving incentives in the Medicare program [Internet]. Washington (DC): MedPAC; 2009 Jun [cited 2009 Jun 15]. Available from: http://www.medpac.gov/documents/Jun09 EntireReport.pdf

39. Steinbrook R. Saying no isn't NICE- the travails of Britain's National Institute for Health and Clinical Excellence. N Engl J Med. 2008;359(19):1977-81.

40. Moon M, Smith B, Gustafson S. Creating a center for evidence-based medicine [Internet]. Washington (DC): MedPAC; 2008 Feb [cited 2009 Jun 11]. Available from: http://www.medpac.gov/documents/Feb08 Center_EvidenceBased_CONTRACTOR_NR.pdf

41. Duckett SJ. Drug policy down under: Australia’s Pharmaceutical Benefits Scheme. Health Care Financ Rev. 2004;25(3):55-67.

42. Neumann PJ. Emerging lessons from the Drug Effectiveness Review Project. Health Aff (Millwood). 2006;25:w262-71.

43. Clancy CM, Cronin K. Evidence-based decision making: global evidence, local decisions. Health Aff (Millwood). 2005;24(1):151-62

44. Institute of Medicine. Initial national priorities for comparative effectiveness research. Chap. 2. Washington (DC): National Academies Press; 2009. 